\title{
Dose Response to Aerosolized Perflubron in a Neonatal Swine Model of Lung Injury
}

\author{
MICHAEL ANDREAS KANDLER, KATHARINA VON DER HARDT, NELLY GERICKE, \\ MARTIN CHADA, JÖRG DÖTSCH, AND WOLFGANG RASCHER
}

Klinik für Kinder und Jugendliche der Universität Erlangen-Nürnberg, D-91054 Erlangen, Germany

\begin{abstract}
Aerosolized perfluorocarbon (PFC) improves gas exchange, lung mechanics, and pulmonary artery pressure. The objective of this intervention was to study the dose-response effect to aerosolized perfluorooctylbromide (PFOB; perflubron, LiquiVent, Alliance Pharmaceutical Corp.) in surfactant-depleted piglets. After induction of lung injury by saline lavage, 25 newborn piglets were randomly assigned to receive $0,1.25,2.5,5.0$, or 7.5 $\mathrm{mL} / \mathrm{kg}$ aerosolized PFOB per hour. A 2-h therapy period was followed by a 3-h observation period. In all animals, respiratory support was performed with intermittent mandatory ventilation. After aerosol treatment and $3 \mathrm{~h}$ of observation, arterial oxygen pressure was similarly improved in the $2.5-, 5.0-$, and $7.5-\mathrm{mL}$. $\mathrm{kg}^{-1} \cdot \mathrm{h}^{-1}$ aerosol-PFOB groups and higher compared with the $1.25-\mathrm{mL} \cdot \mathrm{kg}^{-1} \cdot \mathrm{h}^{-1}$ aerosol-PFOB $(P<0.01)$ and the control groups $(P<0.001)$. Compared with the control group, arterial carbon dioxide pressure was significantly reduced with 2.5-, 5.0-, and $7.5-\mathrm{mL} \cdot \mathrm{kg}^{-1} \cdot \mathrm{h}^{-1}$ aerosol-PFOB $(P<0.001)$. Treatment with $1.25 \mathrm{~mL} \cdot \mathrm{kg}^{-1} \cdot \mathrm{h}^{-1}$ aerosol-PFOB did not significantly affect arterial carbon dioxide pressure. The $20 \%$ terminal dynamic compliance/dynamic compliance was significantly improved in the groups that received $2.5,5.0$, and $7.5 \mathrm{~mL} \cdot \mathrm{kg}^{-1}$. $\mathrm{h}^{-1}$ aerosol-PFOB compared with control animals. Mean pulmonary artery pressure was lower after therapy with 5.0 and 7.5
\end{abstract}

\section{ABSTRACT}

$\mathrm{mL} \cdot \mathrm{kg}^{-1} \cdot \mathrm{h}^{-1}$ aerosol-PFOB $(P<0.01)$ than in the control group. IL-1 $\beta$ gene expression in lung tissue was significantly reduced with PFOB $1.25 \mathrm{~mL} \cdot \mathrm{kg}^{-1} \cdot \mathrm{h}^{-1}$. In summary, aerosolized PFOB improved terminal dynamic compliance, pulmonary gas exchange, and pulmonary artery pressure in a dosedependent manner. In terms of oxygenation and lung mechanics, the optimum dose was between 2.5 and $5 \mathrm{~mL} \cdot \mathrm{kg}^{-1} \cdot \mathrm{h}^{-1}$. (Pediatr Res 56: 191-197, 2004)
Abbreviations
$\mathrm{FIO}_{2}$, fraction of inspired oxygen
FRC, functional residual capacity
IMV, intermittent mandatory ventilation
LV, low-volume
MPAP, mean pulmonary artery pressure
$\mathrm{PaCO}_{2}$, arterial carbon dioxide pressure
$\mathrm{PaO}_{2}$, arterial oxygen pressure
PEEP, positive end expiratory pressure
PFC, perfluorocarbon
PFOB, perfluorooctylbromide
PIP, peak inspiratory pressure
PLV, partial liquid ventilation

Partial liquid ventilation (PLV) with perfluorocarbons (PFCs) has been developed to ameliorate gas exchange in severe respiratory distress syndrome (1). Respiratory distress syndrome highly contributes to deaths that occur during intensive care treatment. In preterm infants, surfactant deficiency, often in combination with infections, leads to respiratory distress syndrome with the need for intensive respiratory support. Mechanical ventilation itself can induce pulmonary injury via shear stress forces, initiating an inflammatory reaction (2-4).

Received February 27, 2003; accepted January 12, 2004.

Correspondence: Michael A. Kandler, M.D., Universitätsklinik für Kinder und Jugendliche, Loschgestr. 15, 91054 Erlangen, Germany; e-mail: michael.kandler@web.de

Supported by grant of the IZKF (Center for Interdisciplinary Clinical Research), University Erlangen-Nuernberg. Perflubron was kindly provided by Alliance Pharmaceutical Corp.

M.A.K. and K.v.d.H. contributed equally to this work.

DOI: 10.1203/01.PDR.0000132667.47744.F4
This inflammatory process may finally induce irreversible lung damage. In preterm infants, this sequence of events results in chronic lung disease known as bronchopulmonary dysplasia (5). This disease cannot yet be completely prevented by lung protective ventilation strategies such as high-frequency oscillatory ventilation (6). PLV was intended not only to improve oxygenation but also to reduce ventilator-induced lung injury. High gas transport capacity, low surface tension, and chemical inertness make PFCs suitable for respiratory support. PFCs have been used for partial liquid ventilation in animal models as well as in preterm infants $(7,8)$, neonates (9), and adults (10-12). In PLV, lungs are filled with PFC to functional residual capacity and difficulties may occur during the filling and weaning period (13). The question of how to monitor the actual PFC filling volume in the lung and how to regulate PFC substitution for evaporative loss is not yet definitively solved (14-19). Weaning from PLV results in a deterioration in gas 
exchange (20). In contrast, aerosolization, using small volumes of FC77, was shown to improve gas exchange and lung mechanics persistently $(20)$ and to reduce ventilator-associated lung injury at least as potently as PLV (21). Vaporization of perfluorohexane has been shown to improve gas exchange in oleic acid-induced lung injury in sheep (22). This technique, using two anesthetic vaporizers calibrated for PFC, requires PFCs with high vapor pressure, such as perfluorohexane (vapor pressure $273 \mathrm{~mm} \mathrm{Hg}$ at $30^{\circ} \mathrm{C}$ ). So far, no data exist on the efficacy of aerosolized perfluorooctylbromide (PFOB), which has been purified to medical grade and which is the only PFC that has been available for large, controlled, clinical trials on partial liquid ventilation (13) (perflubron, LiquiVent, Alliance Pharmaceutical Corp.). Differences in vapor pressure or kinematic viscosity between PFOB and FC77 [which has been applied in previous aerosol experiments $(20,21)]$ may influence the aerosol properties. The efficacy of aerosolized PFC delivery might be modified by the evaporation rate of PFC from the lung, by the distribution of PFC within the airways, or by differences in the size of droplets reaching bronchioli or alveolar space.

Aerosolized FC77 showed a significant therapeutic effect at a dose of $10 \mathrm{~mL} \cdot \mathrm{kg}^{-1} \cdot \mathrm{h}^{-1}$. Because of differences in molecular structure and lower vapor pressure, the optimal dose for aerosolized PFOB could differ from that of FC77. Differences in vapor pressure implies different evaporation rates. The optimal dose of PFOB needed for effective aerosolization therapy has not yet been investigated. Therefore, we designed a dose-response study for aerosolized PFOB in surfactantdepleted piglets.

\section{METHODS}

Subjects. Twenty-five piglets with a body weight of 3.3-4.2 $\mathrm{kg}$ were included in the study. The animal experiment was approved by the Animal Care Committee of the university and the government of Mittelfranken, Germany, and performed according to the guidelines of the National Institutes of Health. Data of all piglets were available for clinical evaluation.

Animal preparation, lung injury, and therapy groups. Operative preparation, anesthesia, and paralysis of animals [ketamine $\left(15 \mathrm{mg} \cdot \mathrm{kg}^{-1} \cdot \mathrm{h}^{-1}\right)$, fentanyl $\left(0.01 \mathrm{mg} \cdot \mathrm{kg}^{-1} \cdot \mathrm{h}^{-1}\right)$, midazolam $\left(1.5 \mathrm{mg} \cdot \mathrm{kg}^{-1} \cdot \mathrm{h}^{-1}\right)$, and vecuronium $(0.2 \mathrm{mg}$. $\left.\mathrm{kg}^{-1} \cdot \mathrm{h}^{-1}\right)$ ] were performed as described previously $(20,21)$. Briefly, after tracheotomy, a sheath $(4.5 \mathrm{~F}$, check-flo performer introducer set, Cook, Mönchengladbach, Germany) was inserted into the right jugular vein and a thermodilution catheter (4 F; Arrow, Erding, Germany) was inserted into the pulmonary artery. An arterial catheter (20 G; Arrow) was inserted into the left femoral artery. A sensor for online blood gas monitoring (Paratrend 7; Agilent, Böblingen, Germany) was introduced in the arterial catheter. Arterial blood gas analysis was performed every 15 min during treatment and every 30 min thereafter (ABL 330; Radiometer, Copenhagen, Denmark). Intermittent mandatory ventilation (IMV) was performed with a time-cycled, pressure-controlled neonatal respirator (Infant Star 950; Mallinckrodt, Hennef, Germany). During operative preparation, a peak inspiratory pressure (PIP) of $20 \mathrm{~cm} \mathrm{H}_{2} \mathrm{O}$, a positive end expiratory pressure (PEEP) of 4 $\mathrm{cm} \mathrm{H}_{2} \mathrm{O}$, a fraction of inspired oxygen $\left(\mathrm{FiO}_{2}\right)$ of 1.0 , and a frequency of 40 breaths/min was used. Before lavage, frequency was augmented to 50 breaths $/ \mathrm{min}$. Respiratory gas was warmed to $39^{\circ} \mathrm{C}$ and humidified (MR 700; AGM Fisher \& Paykel, Welzheim, Germany). Dynamic compliance was recorded with a hot-wire anemometer (MIM GmbH, Krugzell, Germany), computed with the neonatal respiration monitoring Florian NRM-200 (MIM). In addition, C20/c (compliance during the last $20 \%$ of inspiration/total compliance), a marker of pulmonary overdistension, was computed (23) (neonatal respiration monitoring Florian NRM-200, MIM). In pulmonary overdistension, $\mathrm{C} 20 / \mathrm{c}$ is low. Cardiac index was measured by thermodilution method before lavage, before treatment, and at the end of the observation period.

Lung injury was induced by repeated bronchoalveolar lavage (24) using $0.9 \% \mathrm{NaCl}$ at $39^{\circ} \mathrm{C}, 30 \mathrm{~mL} / \mathrm{kg}$ per side. During lavage, PIP and PEEP were increased to 32 and $8 \mathrm{~cm} \mathrm{H}_{2} \mathrm{O}$, respectively. Lung injury was considered successful when the arterial oxygen pressure $\left(\mathrm{PaO}_{2}\right)$ remained below $80 \mathrm{~mm} \mathrm{Hg}$ for a period of $60 \mathrm{~min}$. The animals were randomized to five different groups of five animals each, receiving different doses of PFOB (Alliance Pharmaceutical Corp., San Diego, CA, U.S.A.) as aerosol via an inhalation catheter (AerProbe; Trudell Medical Inc., London, Canada). The tip of the catheter was placed at the distal end of the endotracheal tube; $100 \%$ oxygen flow was used to achieve a driving pressure of 45 PSI.

PFOB aerosol was applied at $0,1.25,2.5,5$, and $7.5 \mathrm{~mL}$. $\mathrm{kg}^{-1} \cdot \mathrm{h}^{-1}$. Aerosolization of PFC at the distal end of the endotracheal tube leads to an $\sim 100 \%$ efficiency of PFC delivery. In all groups, respiratory support was performed with identical respiratory settings (PEEP, $8 \mathrm{~cm} \mathrm{H}_{2} \mathrm{O}$; PIP, $32 \mathrm{~cm}$ $\mathrm{H}_{2} \mathrm{O} ; \mathrm{FIO}_{2}, 1.0,50$ breaths/min). After $2 \mathrm{~h}$, PFOB application was stopped and IMV was continued for another $3 \mathrm{~h}$. The control group received IMV for $5 \mathrm{~h}$.

Cytokine gene expression in lung tissue. RNA extraction, reverse transcription, and TaqMan PCR were performed as described previously $(21,25,26)$. Gene expression was related to $\beta$-actin as housekeeping gene.

Data analysis. Data analysis was performed with Microsoft Office and Graph Pad PRISM. Values are expressed as mean \pm SEM. After testing for Gaussian distribution, two-way ANOVA was used for comparison of the groups. In case of significance, Bonferroni post hoc test was applied, respectively. For cytokine gene expression, Kruskal-Wallis test was used for comparison between the groups. In case of significance, Dunn's post hoc test was applied, respectively. $P<0.05$ was considered significant.

\section{RESULTS}

Aerosol therapy with PFOB was well tolerated. There were no deaths or other unexpected events in any of the groups. Mean weight of the animals was not different between the groups (mean $\pm \mathrm{SD}$ ): control, $3.59 \pm 0.3 \mathrm{~kg}$; PFOB $1.25 \mathrm{~mL}$ $\cdot \mathrm{kg}^{-1} \cdot \mathrm{h}^{-1}, 3.68 \pm 0.3 \mathrm{~kg}$; PFOB $2.5 \mathrm{~mL} \cdot \mathrm{kg}^{-1} \cdot \mathrm{h}^{-1}, 3.74$ $\pm 0.2 \mathrm{~kg}$; PFOB $5.0 \mathrm{~mL} \cdot \mathrm{kg}^{-1} \cdot \mathrm{h}^{-1}, 3.69 \pm 0.1 \mathrm{~kg}$; PFOB 7.5 
$\mathrm{mL} \cdot \mathrm{kg}^{-1} \cdot \mathrm{h}^{-1}, 3.69 \pm 0.3 \mathrm{~kg}$. Mean age of the animals was $11 \pm 0.9 \mathrm{~d}$; there was no difference in age between the groups.

Oxygenation. $\mathrm{PaO}_{2}$ improved significantly in all PFOBtreated groups. Significantly higher values for $\mathrm{PaO}_{2}$ compared with the control group were noticed in all PFOB-treated groups. Differences started to be significant $210 \mathrm{~min}$ after the start of $1.25 \mathrm{~mL} \cdot \mathrm{kg}^{-1} \cdot \mathrm{h}^{-1}$ PFOB aerosol $(P<0.05), 30 \mathrm{~min}$ after the start of $2.5 \mathrm{~mL} \cdot \mathrm{kg}^{-1} \cdot \mathrm{h}^{-1}$ PFOB aerosol $(P<0.01)$, $60 \mathrm{~min}$ after the start of $5 \mathrm{~mL} \cdot \mathrm{kg}^{-1} \cdot \mathrm{h}^{-1}$ PFOB aerosol $(P<$ 0.05 ), and $45 \mathrm{~min}$ after the start of $7.5 \mathrm{~mL} \cdot \mathrm{kg}^{-1} \cdot \mathrm{h}^{-1}$ PFOB aerosol $(P<0.01)$. In all PFOB-treated groups, $\mathrm{PaO}_{2}$ was significantly higher than in the control group at the end of the observation period $(P<0.001)$. Comparing the PFOB-treated groups, $\mathrm{PaO}_{2}$ was significantly higher with $2.5,5$, and $7.5 \mathrm{~mL}$ $\cdot \mathrm{kg}^{-1} \cdot \mathrm{h}^{-1}$ PFOB than with $1.25 \mathrm{~mL} \cdot \mathrm{kg}^{-1} \cdot \mathrm{h}^{-1}$ (Fig. 1). The cumulative PFOB dose at the point where $\mathrm{PaO}_{2}$ became significantly different from control was $1.25 \mathrm{~mL} / \mathrm{kg}$ with PFOB 2.5 $\mathrm{mL} \cdot \mathrm{kg}^{-1} \cdot \mathrm{h}^{-1}, 5 \mathrm{~mL} / \mathrm{kg}$ with PFOB $5 \mathrm{~mL} \cdot \mathrm{kg}^{-1} \cdot \mathrm{h}^{-1}$, and $5.6 \mathrm{~mL} / \mathrm{kg}$ with PFOB $7.5 \mathrm{~mL} \cdot \mathrm{kg}^{-1} \cdot \mathrm{h}^{-1}$. With $1.25 \mathrm{~mL}$. $\mathrm{kg}^{-1} \cdot \mathrm{h}^{-1}$ PFOB, values became significant only after the end of treatment (PFOB evaporation not taken into account).

$\mathrm{CO}_{2}$ removal. No significant changes in arterial carbon dioxide tension were seen with $1.25 \mathrm{~mL} \cdot \mathrm{kg}^{-1} \cdot \mathrm{h}^{-1}$ PFOB. With all other doses, $\mathrm{PacO}_{2}$ fell significantly compared with control animals. The difference started to be significant for 2.5 $\mathrm{mL} \cdot \mathrm{kg}^{-1} \cdot \mathrm{h}^{-1}$ PFOB at $75 \mathrm{~min}$ after therapy start $(P<0.05)$, for $5 \mathrm{~mL} \cdot \mathrm{kg}^{-1} \cdot \mathrm{h}^{-1}$ PFOB at $90(P<0.05)$, and for $7.5 \mathrm{~mL}$ $\cdot \mathrm{kg}^{-1} \cdot \mathrm{h}^{-1}$ PFOB at $105 \min (P<0.01)$ after the start of therapy. At the end of the observation period (starting at 270 $\min$ ), there were no differences between the groups after spontaneous improvement in $\mathrm{PaCO}_{2}$ in the control group. The cumulative PFOB dose at the point where $\mathrm{PaCO}_{2}$ became significantly different from control was $3.1 \mathrm{~mL} / \mathrm{kg}$ with PFOB
$2.5 \mathrm{~mL} \cdot \mathrm{kg}^{-1} \cdot \mathrm{h}^{-1}, 7.5 \mathrm{~mL} / \mathrm{kg}$ with PFOB $5 \mathrm{~mL} \cdot \mathrm{kg}^{-1} \cdot \mathrm{h}^{-1}$, and $13.1 \mathrm{~mL} / \mathrm{kg}$ with PFOB $7.5 \mathrm{~mL} \cdot \mathrm{kg}^{-1} \cdot \mathrm{h}^{-1}$ (PFOB evaporation not taken into account). Details are presented in Fig. 2.

Pulmonary artery pressure. Mean pulmonary artery pressure (MPAP) was significantly different from control animals using 5 and $7.5 \mathrm{~mL} \cdot \mathrm{kg}^{-1} \cdot \mathrm{h}^{-1}$ PFOB. With $5 \mathrm{~mL} \cdot \mathrm{kg}^{-1} \cdot \mathrm{h}^{-1}$ PFOB, MPAP was significantly lower than in the control group at 90 min of therapy $(P<0.01)$ and with $7.5 \mathrm{~mL} \cdot \mathrm{kg}^{-1} \cdot \mathrm{h}^{-1}$ PFOB at $45 \min (P<0.05)$ of therapy. MPAP was not significantly different from the control group in the 1.25 and $2.5 \mathrm{~mL} \cdot \mathrm{kg}^{-1} \cdot \mathrm{h}^{-1}$ PFOB groups. Further details are shown in Fig. 3

Arterial pressure. Mean arterial pressure was not affected in any of the treatment groups compared with the control group.

Dynamic compliance. Although dynamic compliance tended to be higher with $2.5,5$, and $7.5 \mathrm{~mL} \cdot \mathrm{kg}^{-1} \cdot \mathrm{h}^{-1}$, significant differences compared with the control group were not found (Fig. 4). C20/c was significantly different from control animals in all PFOB-treated groups. Differences to the control group were not significant before $120 \min (7.5 \mathrm{~mL}$. $\mathrm{kg}^{-1} \cdot \mathrm{h}^{-1}$ PFOB, $\left.P<0.05\right)$ and $150 \min \left(2.5\right.$ and $5 \mathrm{~mL} \cdot \mathrm{kg}^{-1}$ $\cdot \mathrm{h}^{-1}$ PFOB, $P<0.05$ and 0.01 , respectively) after therapy start. Details are shown in Fig. 5.

Cardiac index. Cardiac index $\left(\mathrm{L} \cdot \mathrm{min}^{-1} \cdot \mathrm{m}^{-2}\right)$ before lavage/before treatment/at the end of the observation period (mean \pm SEM) was $0.65 \pm 0.11 / 0.73 \pm 0.06 / 0.81 \pm 0.08$ in the control group, $0.78 \pm 0.07 / 0.85 \pm 0.06 / 0.83 \pm 0.09$ with PFOB $1.25 \mathrm{~mL} \cdot \mathrm{kg}^{-1} \cdot \mathrm{h}^{-1}, 0.73 \pm 0.08 / 0.69 \pm$ $0.06 / 0.53 \pm 0.06$ with PFOB $2.5 \mathrm{~mL} \cdot \mathrm{kg}^{-1} \cdot \mathrm{h}^{-1}, 0.67 \pm$ $0.03 / 0.68 \pm 0.07 / 0.47 \pm 0.03$ with PFOB $5 \mathrm{~mL} \cdot \mathrm{kg}^{-1} \cdot \mathrm{h}^{-1}$, and $0.80 \pm 0.01 / 0.72 \pm 0.09 / 0.55 \pm 0.04$ with PFOB 7.5 $\mathrm{mL} \cdot \mathrm{kg}^{-1} \cdot \mathrm{h}^{-1}(\mathrm{NS})$.

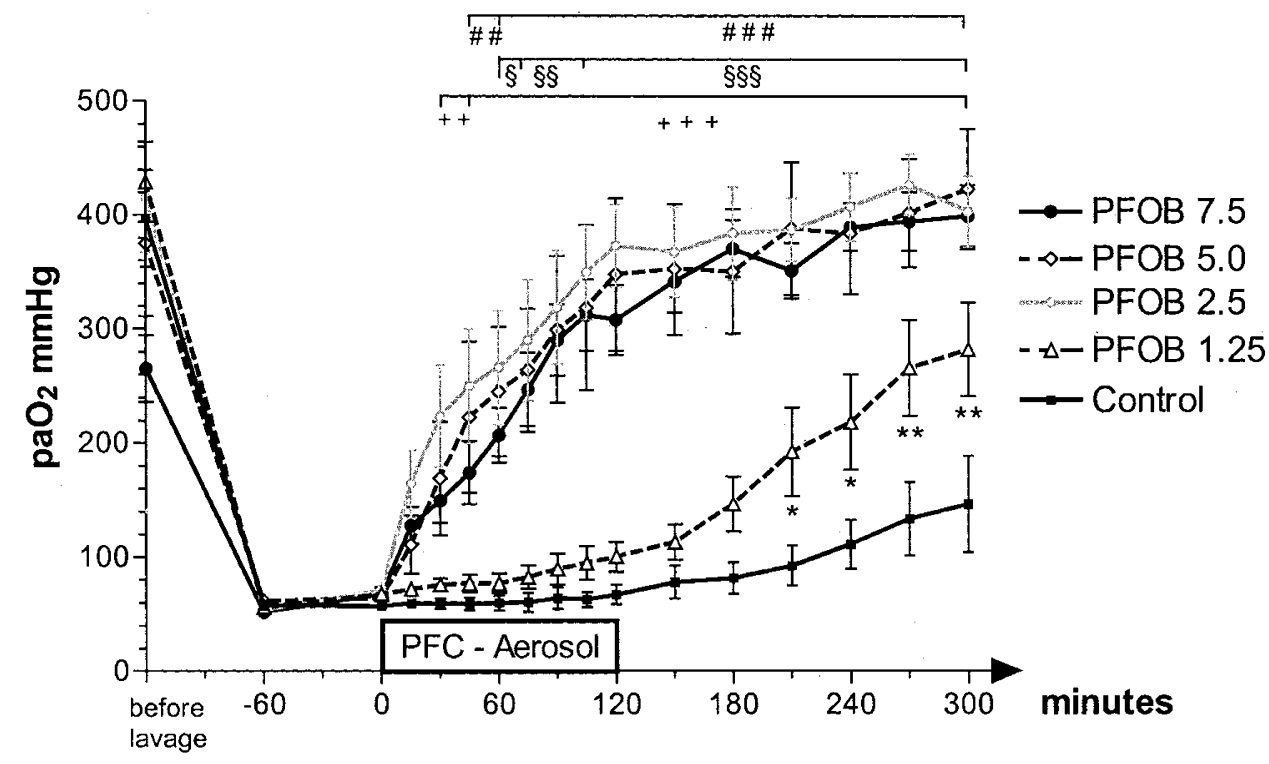

Figure 1. Arterial oxygen tension $\left(\mathrm{PaO}_{2}\right)$ in surfactant-depleted piglets before and after induction of lung injury by bronchoalveolar lavage; before treatment with aerosolized PFOB; during a 2-h treatment period with aerosolized PFOB at a dose of $1.25(n=5), 2.5(n=5), 5(n=5)$, or $7.5(n=5) \mathrm{mL} \cdot \mathrm{kg}^{-1} \cdot \mathrm{h}^{-1}$; and during a 3-h observation period or during $5 \mathrm{~h}$ of IMV (Control; $n=5$ ). Control $v s$ PFOB $1.25 \mathrm{~mL} \cdot \mathrm{kg}^{-1} \cdot \mathrm{h}^{-1}: * P<0.05, * * P<0.01$; control $v s$ PFOB $2.5 \mathrm{~mL} \cdot \mathrm{kg}^{-1} \cdot \mathrm{h}^{-1}:++P<0.01,+++P<0.001$; control vs PFOB $5.0 \mathrm{~mL} \cdot \mathrm{kg}^{-1} \cdot \mathrm{h}^{-1}: \S P<0.05, \S \S P<0.01$, $\S \S P<0.001$; control vs PFOB $7.5 \mathrm{~mL}$ $\cdot \mathrm{kg}^{-1} \cdot \mathrm{h}^{-1}: \# \# P<0.01, \# \# P<0.001$. 


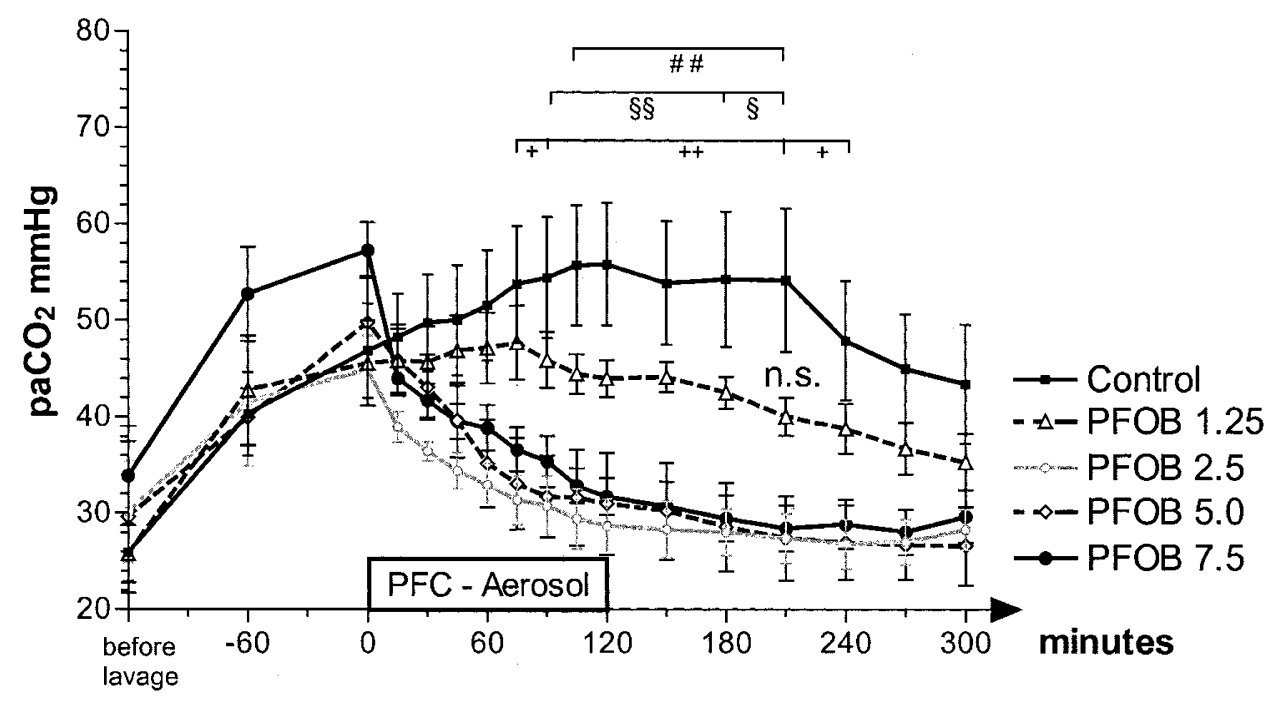

Figure 2. Arterial carbon dioxide tension $\left(\mathrm{PaCO}_{2}\right)$ in surfactant-depleted piglets before and after induction of lung injury by bronchoalveolar lavage; before treatment with aerosolized PFOB; during a 2-h treatment period with aerosolized PFOB at a dose of $1.25(n=5), 2.5(n=5), 5(n=5)$, or $7.5(n=5) \mathrm{mL}$ $\cdot \mathrm{kg}^{-1} \cdot \mathrm{h}^{-1}$; and during a 3-h observation period or during $5 \mathrm{~h}$ of IMV (Control; $n=5$ ). Control vs PFOB $1.25 \mathrm{~mL} \cdot \mathrm{kg}^{-1} \cdot \mathrm{h}^{-1}: \mathrm{NS} ; \mathrm{control}^{-1}$ PFOB $2.5 \mathrm{~mL}$ $\cdot \mathrm{kg}^{-1} \cdot \mathrm{h}^{-1}:+P<0.05,++P<0.01$; control vs PFOB $5.0 \mathrm{~mL} \cdot \mathrm{kg}^{-1} \cdot \mathrm{h}^{-1}: \S P<0.05, \S \S P<0.01$; control vs PFOB $7.5 \mathrm{~mL} \cdot \mathrm{kg}^{-1} \cdot \mathrm{h}^{-1}: \# \# P<0.01$.

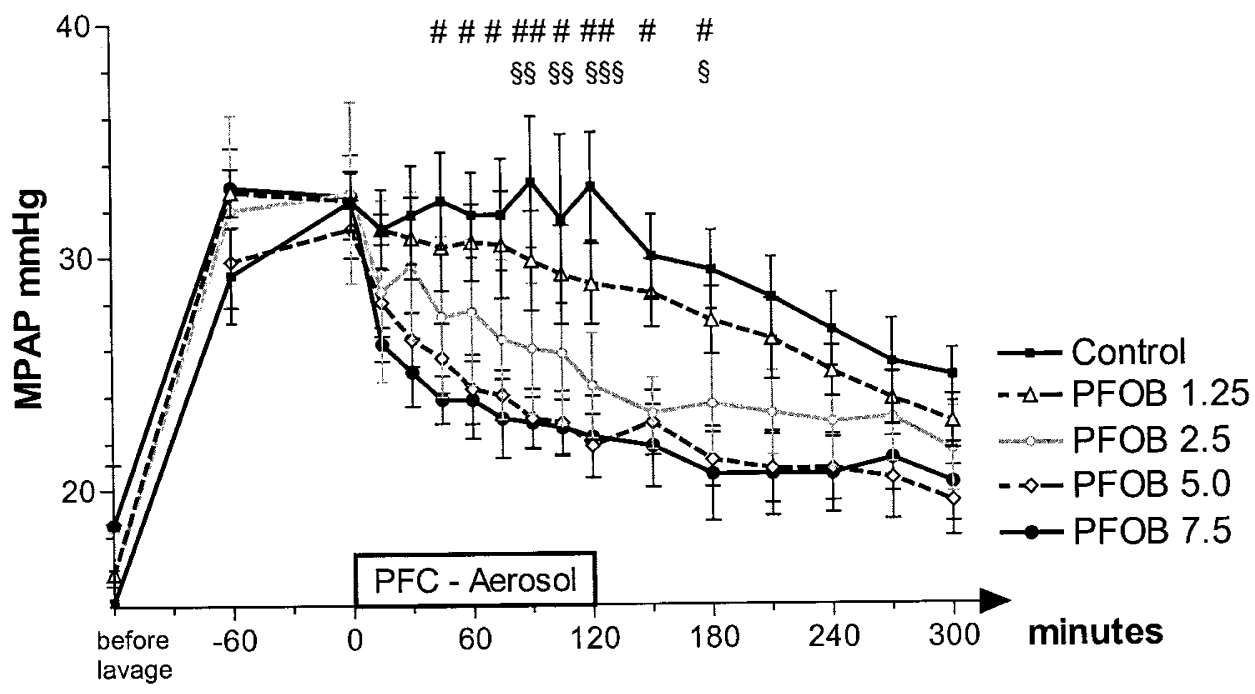

Figure 3. MPAP in surfactant-depleted piglets before and after induction of lung injury by bronchoalveolar lavage; before treatment with aerosolized PFOB; during a 2-h treatment period with aerosolized PFOB at a dose of $1.25(n=5), 2.5(n=5), 5(n=5)$, or $7.5(n=5) \mathrm{mL} \cdot \mathrm{kg}^{-1} \cdot \mathrm{h}^{-1}$; and during a 3-h observation period or during $5 \mathrm{~h}$ of IMV (Control; $n=5$ ). Control vs PFOB $1.25 \mathrm{~mL} \cdot \mathrm{kg}^{-1} \cdot \mathrm{h}^{-1}$ and $5 \mathrm{~mL} \cdot \mathrm{kg}^{-1} \cdot \mathrm{h}^{-1}: \mathrm{NS}$; control vs PFOB $5.0 \mathrm{~mL} \cdot \mathrm{kg}-1 \cdot \mathrm{h}^{-1}: \S P$ $<0.05, \S \S P<0.01$, §§§ $P<0.001$; control vs PFOB $7.5 \mathrm{~mL} \cdot \mathrm{kg}^{-1} \cdot \mathrm{h}^{-1}$ : \#P $<0.05$, \#\#P<0.01.

Cytokine gene expression. IL- $1 \beta / \beta$-actin mRNA expression (relative units, mean \pm SEM) was $2.54 \pm 0.43$ in the control, $0.79 \pm 0.13$ in the PFOB $1.25(P<0.001$ versus control, $P<$ 0.05 versus 2.5 and $\left.7.5 \mathrm{~mL} \cdot \mathrm{kg}^{-1} \cdot \mathrm{h}^{-1}\right), 1.16 \pm 0.15$ in the PFOB 2.5, $1.59 \pm 0.28$ in the PFOB 5, and $1.36 \pm 0.21$ in the PFOB $7.5 \mathrm{~mL} \cdot \mathrm{kg}^{-1} \cdot \mathrm{h}^{-1}$ groups.

\section{DISCUSSION}

In the present study, the effect of aerosolized PFOB on gas exchange and lung mechanics was dose dependent. The optimal dose for PFOB aerosol was within the dose range investigated $\left(1.25-7.5 \mathrm{~mL} \cdot \mathrm{kg}^{-1} \cdot \mathrm{h}^{-1}\right)$. Concerning oxygenation and $\mathrm{C} 20 / \mathrm{c}, 2.5 \mathrm{~mL} \cdot \mathrm{kg}^{-1} \cdot \mathrm{h}^{-1}$ PFOB aerosol is sufficient for therapy of acute respiratory distress syndrome in this experi- mental model. However, higher doses $\left(5 \mathrm{~mL} \cdot \mathrm{kg}^{-1} \cdot \mathrm{h}^{-1}\right)$ are required for reduction of pulmonary arterial pressure. Possible explanation for this observation remains speculative. PFOB aerosol at a dose of $2.5 \mathrm{~mL} \cdot \mathrm{kg}^{-1} \cdot \mathrm{h}^{-1}$ might dilate blood vessels in well-ventilated alveoli, whereas PFOB aerosol at a dose of $5 \mathrm{~mL} \cdot \mathrm{kg}^{-1} \cdot \mathrm{h}^{-1}$ might also dilate blood vessels in less ventilated alveoli. In contrast to inhaled vasodilating agents such as nitric oxide (27) or iloprost (28), reaching predominantly ventilated lung areas, PFOB aerosol might additionally recruit collapsed alveoli for ventilation. This would lead to consecutive vasodilation of corresponding pulmonary arterial vessels. However, recruitment of alveoli has not been measured directly. The difference in dose response of oxygenation and pulmonary arterial pressure might show that the reduction 


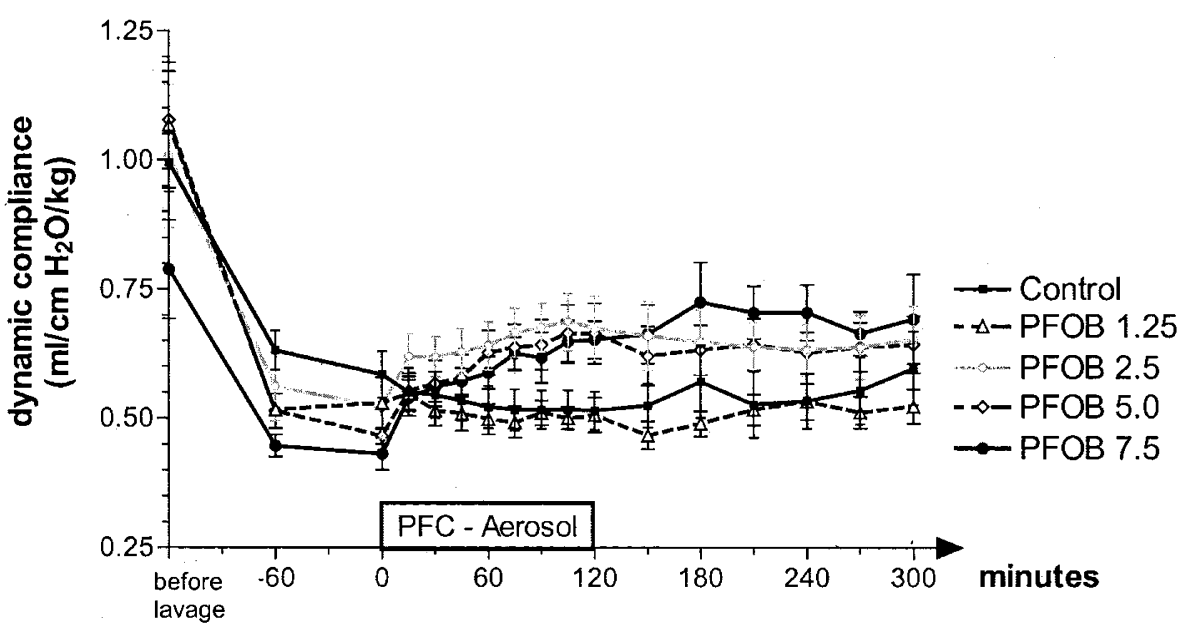

Figure 4. Dynamic compliance $\left(\mathrm{mL} \cdot \mathrm{cm} \mathrm{H}_{2} \mathrm{O}^{-1} \cdot \mathrm{kg}^{-1}\right)$ in surfactant-depleted piglets before and after induction of lung injury by bronchoalveolar lavage; before treatment with aerosolized PFOB; during a 2-h treatment period with aerosolized PFOB at a dose of $1.25(n=5), 2.5(n=5), 5(n=5)$, or $7.5(n=$ 5) $\mathrm{mL} \cdot \mathrm{kg}^{-1} \cdot \mathrm{h}^{-1}$; and during a 3-h observation period or during $5 \mathrm{~h}$ of IMV (Control; $n=5$ ).

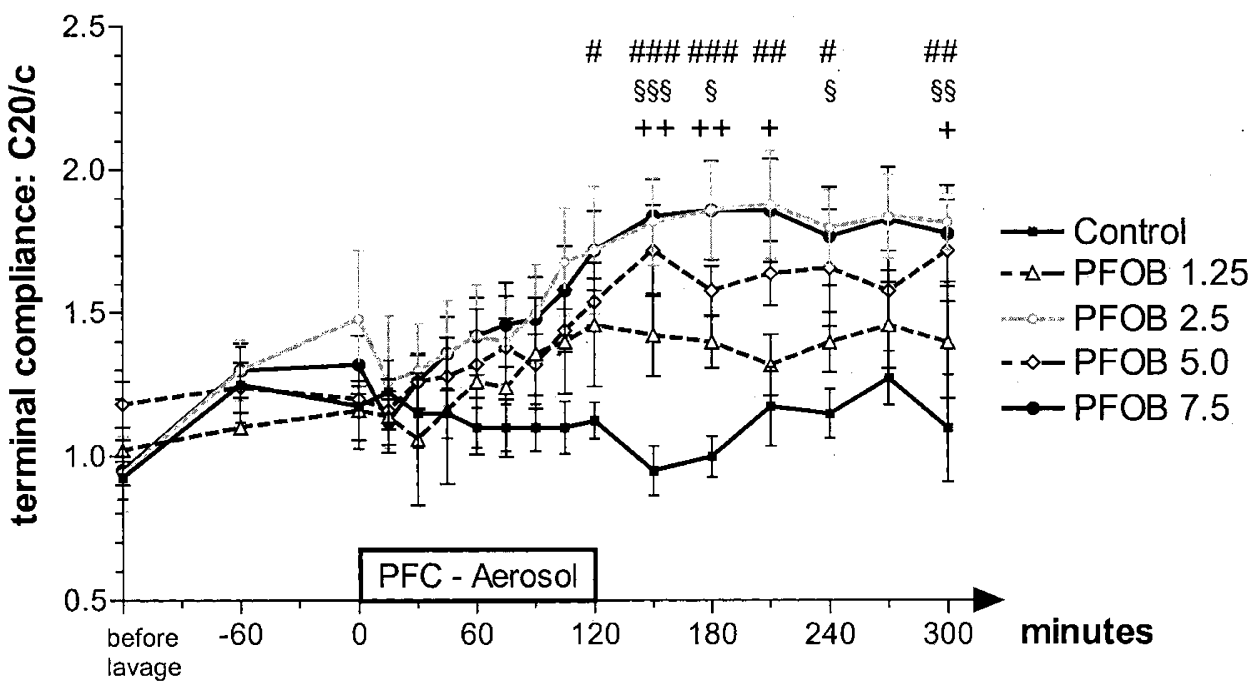

Figure 5. C20/c in surfactant-depleted piglets before and after induction of lung injury by bronchoalveolar lavage; before treatment with aerosolized PFOB; during a 2-h treatment period with aerosolized PFOB at a dose of $1.25(n=5), 2.5(n=5), 5(n=5)$, or $7.5(n=5) \mathrm{mL} \cdot \mathrm{kg}^{-1} \cdot \mathrm{h}^{-1}$; and during a 3 -h observation period or during $5 \mathrm{~h}$ of IMV (Control; $n=5$ ). Control vs PFOB $1.25 \mathrm{~mL} \cdot \mathrm{kg}^{-1} \cdot \mathrm{h}^{-1}$ : NS; control vs PFOB $2.5 \mathrm{~mL} \cdot \mathrm{kg}^{-1} \cdot \mathrm{h}^{-1}:+P<0.05,++P<0.01$; control vs PFOB $5.0 \mathrm{~mL} \cdot \mathrm{kg}^{-1} \cdot \mathrm{h}^{-1}: \S P<0.05, \S \S P<0.01$, $\S \S P<0.001$; control vs PFOB $7.5 \mathrm{~mL} \cdot \mathrm{kg}^{-1} \cdot \mathrm{h}^{-1}: \# P<0.05$, \#\#P<0.01, \#\#P $<0.001$.

of pulmonary arterial pressure by aerosolized PFOB is not mediated exclusively by oxygen-induced pulmonary vasodilation. Other vasodilative mechanisms of PFOB, such as reduction of surface tension with consecutively improved compliance, could have been effective in this model. A direct vasodilating mechanism of PFOB has not yet been described and should not be concluded from the data. The data clearly demonstrate that a dose of $7.5 \mathrm{~mL} \cdot \mathrm{kg}^{-1} \cdot \mathrm{h}^{-1}$ is not of further benefit. However, no adverse effects could be seen with this dose during this short-term experiment. In the PFOB $7.5 \mathrm{~mL}$. $\mathrm{kg}^{-1} \cdot \mathrm{h}^{-1}$ group, the difference in $\mathrm{PaO}_{2}(P<0.001: 7.5 \mathrm{~mL} \cdot$ $\mathrm{kg}^{-1} \cdot \mathrm{h}^{-1}$ versus the other groups) and in dynamic compliance $\left(P<0.01: 7.5\right.$ versus 1.25 and $\left.5 \mathrm{~mL} \cdot \mathrm{kg}^{-1} \cdot \mathrm{h}^{-1}\right)$ before lavage does not necessarily indicate a different degree of health of the animals but might only indicate a different degree of lung recruitment, because in the healthy state, no recruitment maneuver was performed in any of the groups. Otherwise, a different degree of health might have influenced the results. A PFOB dose between 2.5 and $5 \mathrm{~mL} \cdot \mathrm{kg}^{-1} \cdot \mathrm{h}^{-1}$ seems to be sufficient in terms of improvement in oxygenation and lung mechanics. PFC vapor can influence tidal volume measurements with pneumotachographs. Because measurement of compliance is proportional to the measured tidal volume, dynamic compliance is influenced by PFC vapor passing through the pneumotachograph. A falsely high tidal volume as a result of PFC vapor in the pneumotachograph might suggest an improvement of compliance. In a comparable experimental setting, the error in expiratory tidal volume measurements as a result of PFC present in the expired air was $\sim 8 \%$ (preliminary data). By calculating terminal dynamic compliance (dividing terminal $20 \%$ of dynamic compliance/total dynamic compliance), this error will be minimized. The improvement in $\mathrm{C} 20 / \mathrm{c}$ 
suggests a reduction of pulmonary overdistension in the treatment groups that received $\mathrm{PFOB}$ at a dose of $2.5,5$, or $7.5 \mathrm{~mL}$ $\cdot \mathrm{kg}^{-1} \cdot \mathrm{h}^{-1}$.

IL-1 $\beta$ mRNA expression was reduced by treatment with aerosolized PFOB. However, a significant reduction compared with control animals was seen only with PFOB $1.25 \mathrm{~mL} \cdot \mathrm{kg}^{-1}$ $\cdot \mathrm{h}^{-1}$. This may be explained by the short treatment and observation period of only $5 \mathrm{~h}$.

It should be noted that this study on dose-response relationship has been performed in an animal model of neonatal piglets with a body weight of $\sim 3-4 \mathrm{~kg}$. Dose-response might be markedly different in an adolescent or adult situation. If continuously more PFC was applied than the amount evaporating from the lungs, then PFC might accumulate to liquid levels, leading to a changing intrapulmonary distribution of aerosolized and liquid PFC over time. Therefore, overdosing of aerosolized PFC may lead to many of the problems associated with partial liquid ventilation, e.g. in terms of deterioration as a result of inadequate filling volume and in terms of weaning. This may be of considerable importance if therapy with aerosolized PFC is performed for a treatment period longer than $2 \mathrm{~h}$. In contrast to a rapid deterioration of oxygenation after the end of PLV, a persistent improvement of gas exchange and lung mechanics was seen in animals that were treated with aerosolized PFC (20). Therefore, aerosolization of PFC could become a therapeutic option in a clinical setting. The best equilibrium of PFOB aerosol administration and evaporation in a long-term treatment period cannot be established with the data of the present study. Few studies have investigated the effect of liquid low-dose PFOB therapy (29). Doses as low as $3 \mathrm{~mL} / \mathrm{kg}$ of PFOB were shown to be effective when applied in surfactant-depleted piglets on high-frequency oscillatory ventilation (30). However, a filling volume of $30 \mathrm{~mL} / \mathrm{kg}$ of PFOB was shown to be more effective than $15 \mathrm{~mL} / \mathrm{kg}$ in preterm lambs (31). After intratracheal administration of $5-25 \mathrm{~mL} / \mathrm{kg}$ of liquid $\mathrm{PFOB}$ in $5-\mathrm{mL} / \mathrm{kg}$ doses, $\mathrm{PaO}_{2}$ was significantly different from the control group only after administration of $15-25 \mathrm{~mL} / \mathrm{kg}$ in adult pigs (32). In neonatal piglets, PLV with a filling volume of full residual capacity was more effective than a volume of half residual capacity in a bypass model (33). Compared with these data, the optimum dose of $\sim 2.5-5 \mathrm{~mL} / \mathrm{kg}$ of PFOB for aerosolization is considerably low and highly effective. With regard to previously published data obtained with aerosolized FC77 (20), no significant difference was found for gas exchange between animals that were treated with FC77 $\left(10 \mathrm{~mL} \cdot \mathrm{kg}^{-1} \cdot \mathrm{h}^{-1}\right)$ in the previous study and PFOB $\left(2.5,5\right.$, and $\left.7.5 \mathrm{~mL} \cdot \mathrm{kg}^{-1} \cdot \mathrm{h}^{-1}\right)$ in the present study.

In summary, a dose-response relationship was seen with aerosolized PFOB for gas exchange and lung mechanics. An aerosol dose between 2.5 and $5 \mathrm{~mL} / \mathrm{kg}$ could be considered as appropriate in neonatal surfactant-depleted piglets. A sustained benefit of treatment with aerosolized PFOB was seen for hours after the end of PFOB application.

Acknowledgments. The excellent technical assistance of A. Cubra, N. Gromball, K. Popp, K. Scheuerer, and J. Walther is gratefully acknowledged. We thank D. Labahn for excellent assistance. We gratefully acknowledge the supply of the blood gas analyzer ABL 330 (Radiometer, Copenhagen, Denmark) by $\mathrm{T}$. Zocher (Radiometer).

\section{REFERENCES}

1. Shaffer TH, Wolfson MR, Clark LC Jr 1992 Liquid ventilation. Pediatr Pulmonol 14:102-109

2. Haitsma JJ, Uhlig S, Goggel R, Verbrugge SJ, Lachmann U, Lachmann B 2000 Ventilator-induced lung injury leads to loss of alveolar and systemic compartmentalization of tumor necrosis factor-alpha. Intensive Care Med 26:1515-1522

3. Vazquez de Anda GF, Lachmann RA, Verbrugge SJ, Gommers D, Haitsma JJ, Lachmann B 2001 Partial liquid ventilation improves lung function in ventilationinduced lung injury. Eur Respir J 18:93-99

4. Verbrugge SJ, Lachmann B 1999 Mechanisms of ventilation-induced lung injury: physiological rationale to prevent it. Monaldi Arch Chest Dis 54:22-37

5. Speer CP 1999 Inflammatory mechanisms in neonatal chronic lung disease. Eur J Pediatr 158(suppl 1):S18-S22

6. Gerstmann DR, Minton SD, Stoddard RA, Meredith KS, Monaco F, Bertrand JM, Battisti O, Langhendries JP, Francois A, Clark RH 1996 The Provo multicenter early high-frequency oscillatory ventilation trial: improved pulmonary and clinical outcome in respiratory distress syndrome. Pediatrics 98:1044-1057

7. Greenspan JS, Wolfson MR, Rubenstein SD, Shaffer TH 1990 Liquid ventilation of human preterm neonates. J Pediatr 117:106-111

8. Leach CL, Greenspan JS, Rubenstein SD, Shaffer TH, Wolfson MR, Jackson JC, DeLemos R, Fuhrman BP 1996 Partial liquid ventilation with perflubron in premature infants with severe respiratory distress syndrome. The LiquiVent Study Group. N Engl J Med 335:761-767

9. Pranikoff T, Gauger PG, Hirschl RB 1996 Partial liquid ventilation in newborn patients with congenital diaphragmatic hernia. J Pediatr Surg 31:613-618

10. Croce MA, Fabian TC, Patton JH Jr, Melton SM, Moore M, Trenthem LL 1998 Partial liquid ventilation decreases the inflammatory response in the alveolar environment of trauma patients. J Trauma 45:273-280

11. Hirschl RB, Pranikoff T, Wise C, Overbeck MC, Gauger P, Schreiner RJ, Dechert R, Bartlett RH 1996 Initial experience with partial liquid ventilation in adult patients with the acute respiratory distress syndrome. JAMA 275:383-389

12. Hirschl RB, Pranikoff T, Gauger P, Schreiner RJ, Dechert R, Bartlett RH 1995 Liquid ventilation in adults, children, and full-term neonates. Lancet 346:1201-1202

13. Hirschl RB, Croce M, Gore D, Wiedemann H, Davis K, Zwischenberger J, Bartlett RH 2002 Prospective, randomized, controlled pilot study of partial liquid ventilation in adult acute respiratory distress syndrome. Am J Respir Crit Care Med 165:781-787

14. Shaffer TH, Foust R 3rd, Wolfson MR, Miller TF Jr 1997 Analysis of perfluorochemical elimination from the respiratory system. J Appl Physiol 83:1033-1040

15. Miller TF, Milestone B, Stern R, Shaffer TH, Wolfson MR 1999 Effect of single versus multiple dosing on perfluorochemical distribution and elimination during partial liquid ventilation. Pediatr Pulmonol 27:410-418

16. Libros R, Philips CM, Wolfson MR, Shaffer TH 2000 A perfluorochemical loss/ restoration (L/R) system for tidal liquid ventilation. Biomed Instrum Technol 34:351360

17. Philips CM, Weis C, Fox WW, Wolfson MR, Shaffer TH 1999 On-line techniques for perfluorochemical vapor sampling and measurement. Biomed Instrum Technol 33:348-355

18. Weis CM, Fox WW, Philips CM, Wolfson MR, Shaffer TH 2000 Perfluorochemical elimination from the lungs: effect of initial dose. Pediatr Pulmonol 30:324-329

19. Jeng MJ, Trevisanuto D, Weis CM, Fox WW, Cullen AB, Wolfson MR, Shaffer TH 2001 Role of ventilation strategy on perfluorochemical evaporation from the lungs. J Appl Physiol 90:1365-1372

20. Kandler MA, von der Hardt K, Schoof E, Dötsch J, Rascher W 2001 Persistent improvement of gas exchange and lung mechanics by aerosolized perfluorocarbon. Am J Respir Crit Care Med 164:31-35

21. von der Hardt K, Schoof E, Kandler MA, Dötsch J, Rascher W 2002 Aerosolized perfluorocarbon suppresses early pulmonary inflammatory response in a surfactantdepleted piglet model. Pediatr Res 51:177-182

22. Bleyl JU, Ragaller M, Tscho U, Regner M, Kanzow M, Hubler M, Rasche S, Albrecht M 1999 Vaporized perfluorocarbon improves oxygenation and pulmonary function in an ovine model of acute respiratory distress syndrome. Anesthesiology 91:461-469

23. Fisher JB, Mammel MC, Coleman JM, Bing DR, Boros SJ 1988 Identifying lung overdistention during mechanical ventilation by using volume-pressure loops. Pediatr Pulmonol 5:10-14

24. Lachmann B, Robertson B, Vogel J 1980 In vivo lung lavage as an experimental model of the respiratory distress syndrome. Acta Anaesthesiol Scand 24:231-236

25. von der Hardt K, Kandler MA, Popp K, Schoof E, Chada M, Rascher W, Dotsch J 2002 Aerosolized adrenomedullin suppresses pulmonary transforming growth factor-betal and interleukin-1beta gene expression in vivo. Eur J Pharmacol 457:71-76

26. Schoof E, von der Hardt K, Kandler MA, Abendroth F, Papadopoulos T, Rascher W, Dotsch J 2002 Aerosolized perfluorocarbon reduces adhesion molecule gene expression and neutrophil sequestration in acute respiratory distress. Eur J Pharmacol 457:195-200

27. Demirakca S, Dotsch J, Knothe C, Magsaam J, Reiter HL, Bauer J, Kuehl PG 1996 Inhaled nitric oxide in neonatal and pediatric acute respiratory distress syndrome: dose response, prolonged inhalation, and weaning. Crit Care Med 24:1913-1919 
28. Olschewski H, Simonneau G, Galie N, Higenbottam T, Naeije R, Rubin LJ, Nikkho S, Speich R, Hoeper MM, Behr J, Winkler J, Sitbon O, Popov W, Ghofrani HA, Manes A, Kiely DG, Ewert R, Meyer A, Corris PA, Delcroix M, Gomez-Sanchez M, Siedentop H, Seeger W 2002 Inhaled iloprost for severe pulmonary hypertension. N Engl J Med 347:322-329

29. Tutuncu AS, Faithfull NS, Lachmann B 1993 Intratracheal perfluorocarbon administration combined with mechanical ventilation in experimental respiratory distress syndrome: dose-dependent improvement of gas exchange. Crit Care Med 21:962-969

30. Baden HP, Mellema JD, Bratton SL, O’Rourke PP, Jackson JC 1997 High-frequency oscillatory ventilation with partial liquid ventilation in a model of acute respiratory failure. Crit Care Med 25:299-302
31. Wolfson MR, Kechner NE, Roache RF, DeChadarevian JP, Friss HE, Rubenstein SD, Shaffer TH 1998 Perfluorochemical rescue after surfactant treatment: effect of perflubron dose and ventilatory frequency. J Appl Physiol 84:624-640

32. Houmes RJ, Verbrugge SJ, Hendrik ER, Lachmann B 1995 Hemodynamic effects of partial liquid ventilation with perfluorocarbon in acute lung injury. Intensive Care Med 21:966-972

33. Cannon ML, Cheifetz IM, Craig DM, Hubble CL, Quick G, Ungerleider RM, Smith PK, Meliones JN 1999 Optimizing liquid ventilation as a lung protection strategy for neonatal cardiopulmonary bypass: full functional residual capacity dosing is more effective than half functional residual capacity dosing. Crit Care Med 27:1140-1146 